\title{
PRETREATED MUNICIPAL SOLID WASTE BEHAVIOUR IN LABORATORY SCALE LANDFILL
}

\author{
A. A. SIDDIQUI \\ Department of Civil Engineering, Aligarh Muslim University, India.
}

\begin{abstract}
Mechanical biological pretreatment processes are increasingly being employed as a means of diverting biodegradable municipal waste from landfill to comply with the EU Landfill Directive. This will have major implications for the nature of the waste that is disposed of to landfills and hence for the way in which the landfills should be managed. The long-term behaviour of mechanically biologically treated (MBT) waste will be different from that of unprocessed municipal solid waste since the pretreatment process may change its physical, chemical and biological properties. To investigate the impact of the level of pretreatment, large-scale laboratory experiments were carried out on MBT wastes treated to typical UK and German standards. Gas generating potential, leachate quality, settlement characteristics and hydraulic properties of MBT wastes were determined and compared. The research has demonstrated the benefits of pretreatment in substantially reducing the gas generating potential, releasing low levels of total organic carbon and ammoniacal nitrogen and, reducing the long-term settlements due to creep and biodegradation. Data from both MBT wastes followed the same general trend of decreasing hydraulic conductivity and drainable porosity with increasing stress and waste density.
\end{abstract}

Keywords: Biogas, hydraulic conductivity, landfill, leachate, municipal solid waste, porosity, pretreatment.

\section{INTRODUCTION}

The EU Landfill Directive [1] has imposed limits on the amount of biodegradable municipal solid waste (MSW) that may be disposed to landfill. Many European countries (e.g. Germany, Austria) required to comply with the Directive earlier than the UK have chosen mechanical-biological treatment (MBT) as a technology for treating MSW to arrive at the targets set out in the Landfill Directive.

MBT processes combine mechanical processing such as size reduction with biological treatment such as biostabilisation (composting and/or anaerobic digestion) or bio-drying. MBT technologies manipulate and convert raw MSW into different streams that are directed either to minimise pollution potential of biodegradable waste disposal in landfills or to obtain additional value from waste by recovery of recyclable material and waste-derived fuels. In MBT, the organic fraction can be treated with several processes. In particular, biostabilisation process leads to the complete degradation of easily biodegradable organic matter generating a stabilised organic fraction suitable to be landfilled. In contrast, bio-drying process uses the heat produced in the exothermic biochemical process to dry the waste with the lowest conversion of organic carbon, preserving most of its energy content [2-4]. Biodried material can be used to obtain waste-derived fuels such as solid recovered fuel (SRF) or refuse derived fuel (RDF) after the separation of metal, glass and inerts. These fuels have the potential use as co-fuel in cement kilns, power plants and incineration facilities. MBT facilities have been commissioned over recent years, and MBT waste is expected to feature more prominently in residual waste management in the short and medium term.

The focus of the Landfill Directive is solely mechanistic and no official limits or evaluation criteria were specified for the biodegradability parameters of the final product which is intended for landfilling. In Germany, waste pretreatment processes are more advanced and a Landfill Ordinance [5] has set very strict allocation criteria for the landfilling of MBT waste. In contrast, the UK has not defined standards for landfilled MBT waste and a quantitative approach is employed to reduce the 
Table 1: Allocation criteria for landfilling of MBT waste [6-8].

\begin{tabular}{llc}
\hline & \multicolumn{2}{c}{ Limit value } \\
\cline { 2 - 3 } Parameter & Germany & Austria \\
\hline Biological degradability determined as & & \\
$\begin{array}{l}\text { Respiration activity (within 4 days ), } \mathrm{AT}_{4} \\
\text { OR }\end{array}$ & $5 \mathrm{mg} \mathrm{O}_{2} / \mathrm{g} \mathrm{DM}$ & $7 \mathrm{mg} \mathrm{O}_{2} / \mathrm{g} \mathrm{DM}$ \\
$\begin{array}{ll}\text { Gas formation rate (within 21 days), } \mathrm{GB}_{21} \\
\text { Calorific value }\end{array}$ & $20 \mathrm{~L} / \mathrm{kg} \mathrm{DM}$ & $20 \mathrm{~L} / \mathrm{kg} \mathrm{DM}$ \\
\hline
\end{tabular}

amount of biodegradable municipal waste (BMW), which is landfilled in accordance with the Landfill Directive. Table 1 shows the threshold values for the landfilling of MBT waste in Germany and Austria. Besides other limit values, the compliance with 'biological degradability of dry residue in original substance' is represented by respiration activity (oxygen consumption over 4 days) or gas formation potential over 21 days.

Biogas and leachate characteristics of pretreated waste based on small-scale studies have been reported by a few authors (e.g. [6,9-11]). These studies demonstrate that MBT wastes have reduced gas generating potential and leachate strength. Current knowledge regarding settlement characteristics is mainly related to MSW landfills. There are virtually no settlement data for MBT waste landfills. The behaviour of MBT waste will be different from the experiences that have been gained in the past for MSW landfills, and a clear distinction between the creep and biodegradation components of settlement is needed. Powrie and Beaven [12] carried out tests on household waste in a large-scale compression and reported a decrease in hydraulic conductivity as a function of applied stress and density. This trend of decrease in hydraulic conductivity with increasing density and/or applied stress was later corroborated by the work performed by Reddy et al. [13], Olivier and Gourc [14], Durmusoglu et al. [15], and Stoltz et al. [16]. Trends of decreasing porosity with increasing density and/or applied stress are highlighted in studies by Powrie and Beaven [12], Hudson et al. [17], Staub et al. [18], and Stoltz and Gourc [19].

Comprehensive laboratory-scale experiments were carried out in large consolidating anaerobic reactors (CARs) to evaluate the gas generating potential, leachate quality, settlement characteristics and hydraulic properties of MBT wastes.

\section{MATERIALS AND METHODS}

\subsection{Waste samples}

Two different waste materials were studied: UK MBT and German MBT. They originate from two different MBT plants, one in the UK and one in Germany.

\subsubsection{UK MBT waste}

A sample of about $500 \mathrm{~kg}$ of MBT waste was obtained from White's Pit waste processing plant (New Earth Solutions Ltd.), a MBT facility in Southern England. This facility includes a shredder, conveyor belts, magnets, screens and windrows for aerobic composting. The first stage of processing involved mechanical sorting to extract recyclable materials. The remaining waste was shredded and 
Table 2: MBT waste components expressed as dry weight percentages.

\begin{tabular}{lcc}
\hline & \multicolumn{2}{c}{ Percentage of dry mass (\%) } \\
\cline { 2 - 3 } Component & 0.43 & 0.18 \\
\hline Paper & 4.57 & 2.4 \\
Flexible plastics & 6.27 & 5.91 \\
Rigid plastics & 1.57 & 3.22 \\
Wood & 1.33 & 0.63 \\
Textile & 0.18 & 0.25 \\
Rubber & 0.27 & 0.37 \\
Bones & 0.49 & 1.49 \\
Metal & 2.29 & 4.25 \\
Ceramics & 1.73 & 3.17 \\
Stones & 22.77 & 24.36 \\
Glass & 28.95 & 26.75 \\
Unidentified $>5 \mathrm{~mm}$ & 29.15 & 27.02 \\
Unidentified $<5 \mathrm{~mm}$ & 100.00 & 100.00 \\
Total & &
\end{tabular}

screened, and further ferrous metal extracted. The waste was then composted in forced aerated windrows, regularly wetted and turned, in a fully enclosed hall for a period of 6 weeks. The composted material was then screened down to $20 \mathrm{~mm}$ to remove any remaining dry recyclables.

\subsubsection{German MBT waste}

A sample of about $120 \mathrm{~kg}$ of MBT waste was collected from Hannover Waste Treatment Centre, a full-scale MBT plant located in Hannover, Northern Germany. The waste was sorted, shredded and screened, and recyclable materials and metals were removed. The high calorific value fraction (mainly non-recycled paper and plastics) was sent as a RDF to the incineration plant. Waste was then anaerobically digested in fermentation tanks for a period of 3 weeks. The digested material was composted in enclosed windrows for about 6 weeks. The maximum particle size of the residual material was about $60 \mathrm{~mm}$.

\subsection{Waste composition}

MBT waste was sorted manually into various material categories, and the composition of each waste sample by material type (expressed as percentage of the total dry weight) is given in Table 2 . All materials $<5 \mathrm{~mm}$ were placed in the 'unidentified $<5 \mathrm{~mm}$ ' category. The 'unidentified' category represents a mixture of different components that could not be identified or further separated. The unidentified $>5 \mathrm{~mm}$ category consists of particles $>5 \mathrm{~mm}$ whose material could not be identified, usually because they were encased in soil-like material which was impossible to remove without breaking the particle. Owing to different processing of waste in the pretreatment stages, UK MBT waste is slightly different from the German MBT waste.

The average moisture content of the UK MBT waste was found to be $36.1 \%$ of the dry weight. The German MBT waste sample was received oven-dried due to transport, so its moisture content 
was not determined. The values of loss on ignition (LOI), also known as volatile solids content, were $42.91 \%$ and $34.84 \%$ for the UK and German MBT wastes, respectively. The carbon content was $22.68 \%$ and $19.85 \%$, and the nitrogen content was $1.81 \%$ and $1.52 \%$ for the UK and German MBT wastes, respectively.

\subsection{Equipment}

Large-scale CARs were set up in the laboratory to simulate anaerobic conditions in a landfill. The CAR comprises a Perspex cylinder 480-mm diameter, 900-mm tall, and a load delivery system that can apply a constant vertical stress to the waste. In preparation for the experiment, a $10-\mathrm{cm}$ gravel drainage layer was placed at the base of the CAR overlain by a geotextile membrane. The MBT waste was placed in the CAR in 10 successive layers of $4 \mathrm{~kg}$ each compacted to a thickness of $5 \mathrm{~cm}$ by hand tamping. A further layer of gravel (5-cm thick) was placed to give an even distribution of leachate over the top surface of the waste, and was again separated from the waste by a geotextile membrane. Following preparation, the CAR was placed within a compression loading rig to apply the vertical stress and, the leachate was recirculated from the bottom to the top using a peristaltic pump. Biogas production was determined by allowing the gas to build up in the headspace volume to a small positive pressure above ambient atmospheric pressure measured by a pressure sensor. The details of CAR and gas measurement are given in Siddiqui et al. [20].

\subsection{CAR start up and operation}

Long-term testing of each MBT waste was undertaken using two CARs: a control reactor (CAR1) and a test reactor (CAR2) (see Fig. 1). Synthetic leachate containing mineral nutrients and trace elements dissolved in deionised water as described by Florencio et al. [21] was used in this study. CAR2 was filled with $80 \mathrm{~L}$ of leachate comprising an inoculum of anaerobically digested sewage sludge (10\% vol.) derived from an anaerobic digester. This was done to ensure the presence of viable methanogenic bacteria and to accelerate the initiation of methanogenesis. In the control reactor (CAR1), $80 \mathrm{~L}$ of leachate mixed with acetic and propionic acids at a concentration of $10 \mathrm{~g} / \mathrm{l}$ each was added to suppress microbial activity and prevent the onset of methanogenesis. The reactors were then sparged with nitrogen gas to remove any oxygen trapped within the reactor and the leachate was recirculated continuously from the bottom to the top of each reactor. CAR 1 was operated at $\sim 20^{\circ} \mathrm{C}$ in a controlled temperature room and CAR2 was maintained at a constant mesophilic temperature of $30^{\circ} \mathrm{C}$ using a heat blanket to establish a favourable growth environment for the microorganisms in the reactor. The operation of the CARs in this way was designed to isolate settlements due to mechanical creep from those due to biodegradation, by comparing the settlements measured in each. The CARs were operated for 347 and 279 days for the UK MBT and German MBT wastes, respectively. The load was maintained at $50 \mathrm{kPa}$ for the first 286 and 202 days of the experiment on the UK and German MBT wastes, respectively. Thereafter, load was increased to $150 \mathrm{kPa}$ for the remainder of the test in order to investigate any dependence of the creep characteristics of the waste on the applied load.

In addition to the biodegradation and settlement behaviour, the hydraulic properties (hydraulic conductivity and drainable porosity) of each MBT waste were characterised, for which the testing methodology was as follows:

a. Hydraulic properties, i.e. drainable porosity $\left(\mathrm{n}_{\mathrm{d}}\right)$ and saturated hydraulic conductivity $(\mathrm{k})$ at the initial stage were determined in the CARs under no applied load (zero vertical stress). Other parameters such as total porosity $(n)$ and dry density $\left(\rho_{d}\right)$ were also determined at this stage. 
b. A load of $50 \mathrm{kPa}$ was applied in both the CARs and the parameters $n_{d}, k, n$ and, $\rho_{d}$ were determined after $24 \mathrm{~h}$.

c. The CARs were completely sealed and appropriate valves were installed for gas and leachate handling. CAR2 was filled with leachate containing sludge seed and CAR1 with leachate comprising acids as detailed earlier.

d. The CARs were sparged with nitrogen gas to remove oxygen from the system, and then operated with continuous leachate recirculation.

e. The CARs were continuously monitored for biogas, leachate and settlement over periods of 286 and 202 days for the UK MBT waste and German MBT waste, respectively.

f. The load was then increased to $150 \mathrm{kPa}$ and the CARs were monitored for a further 61 and 77 days for the UK and German MBT wastes, respectively.

g. The final hydraulic properties $\left(\mathrm{k}\right.$ and $\left.\mathrm{n}_{\mathrm{d}}\right), \mathrm{n}$, and $\rho_{\mathrm{d}}$ were determined at $150 \mathrm{kPa}$, at the end of each test.

\subsection{Determination of drainable porosity}

The reactor was filled with synthetic leachate to saturate the waste from the base to the top using a peristaltic pump. This was undertaken in stages to saturate only a small proportion of the waste at a time until complete saturation of the waste was achieved. Leachate levels within the piezometers up the side of the reactor were allowed to stabilise before a further volume of synthetic leachate was added. After the waste had been fully saturated, the total porosity of the waste was determined. Then a drainage procedure was carried out on the waste inside the reactor, lasting a period of several hours. The waste was allowed to drain in stages under conditions of free downward gravity. At each stage, small volumes of leachate were drained and the resulting change in hydrostatic head in the waste was measured.

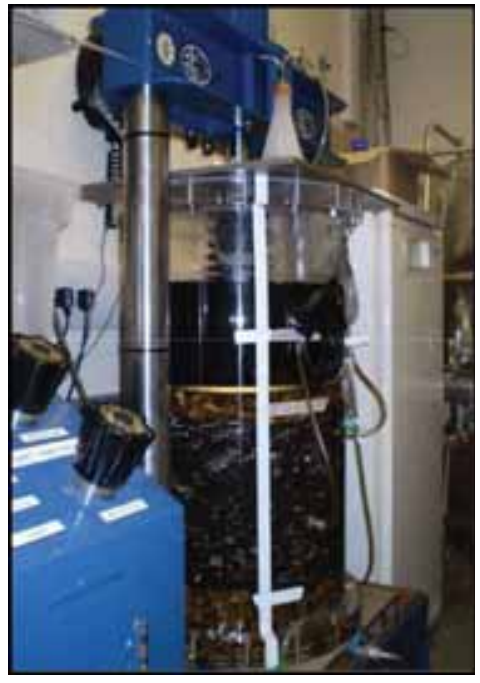

(a)

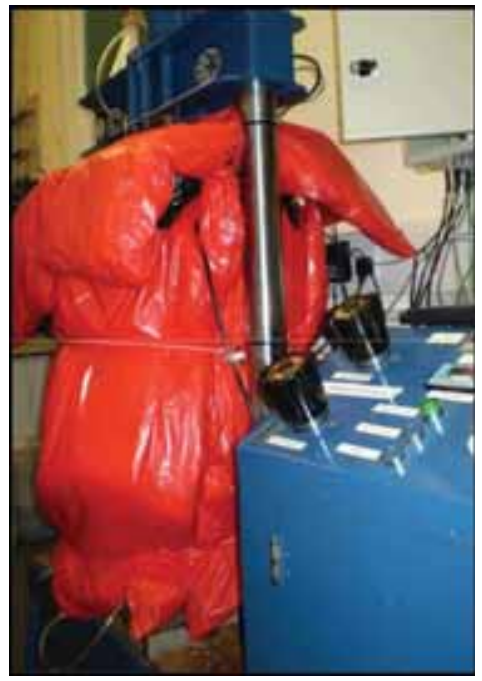

(b)

Figure 1: Consolidating anaerobic reactors (a) CAR1 and (b) CAR2. 
The leachate was drained through the lower outlet and the piezometers on the side of the reactor were used to measure the piezometric head. Piezometric levels were allowed to stabilise before readings were taken. The hydrostatic leachate head indicating the level to which the waste in the reactor had become saturated was plotted against the cumulative volume of leachate drained. The slope of the line through these data points at any particular elevation within the waste is directly related to the drainable porosity as described in Beaven [22].

The drainable porosity of the MBT waste in the CARs was determined at the initial stage (no applied load), at $50 \mathrm{kPa}$, and at $150 \mathrm{kPa}$ after the experiments on biodegradation and settlement behaviour were ended.

\subsection{Determination of saturated hydraulic conductivity}

Following saturation of the waste, leachate was pumped to the top of the CAR using a calibrated peristaltic pump. The leachate inflow was increased steadily until the outflow rate through the lower outlet matched the inflow. The test was run in downward flow direction. An arrangement was made to the CAR to allow a saturated hydraulic conductivity test to be undertaken. Leachate flow from the outlet port was conveyed through a tube connected to a lower end of an inverted T-connector, fastened to a vertical stand whose elevation could be easily altered. The other lower end of the T-connector was connected to a tube that drained leachate to a container. The top end of the T-connector was left open to atmosphere to prevent siphoning effects. Flow was adjusted by raising or lowering the T-connector. The outflow volume and the head at piezometer ports within the waste (at 250 and $400 \mathrm{~mm}$ above the reactor base) were measured every $15 \mathrm{~min}$. The steady-state condition was established when the inflow matched the outflow and the leachate levels in the piezometers were stable. The procedure followed is based on a previous study on MSW [23]. The hydraulic conductivity for this constant head flow test was obtained using the Darcy's equation.

The hydraulic conductivity of the waste in CARs was determined at the initial stage (no applied load), at $50 \mathrm{kPa}$ (before and after degradation), and at $150 \mathrm{kPa}$ after the experiments on biodegradation and settlement behaviour were ended.

\subsection{Analytical procedures}

The biogas composition in the CARs was measured daily as a percentage by volume using an infrared gas analyser GASCARD II Plus. Total organic carbon (TOC) and ammoniacal nitrogen $\left(\mathrm{NH}_{4}-\mathrm{N}\right)$ analyses of leachate were carried out using a high-temperature Dohrmann-Rosemount DC 190 TOC analyser and Foss Tecator Kjeltec System 1002 distillation unit, respectively.

\section{RESULTS AND DISCUSSION}

\subsection{Biogas generating potential}

The daily gas production for the UK and German MBT wastes is illustrated in Fig. 2. The gas production started soon after filling the test reactor, CAR2, for both the UK and German MBT wastes. Biogas production was relatively low during the first week of operation, presumably due to the time taken for the acclimatisation of the methanogenic bacteria and the accumulation of VFA which kept the $\mathrm{pH}$ low. The biogas production then increased and methanogenic conditions were quickly established as confirmed by the change in biogas composition to about $60 \% \mathrm{CH}_{4}$ and $35 \% \mathrm{CO}_{2}$ by volume. The acidogenic phase was virtually absent; probably due to the degradation of some organic 


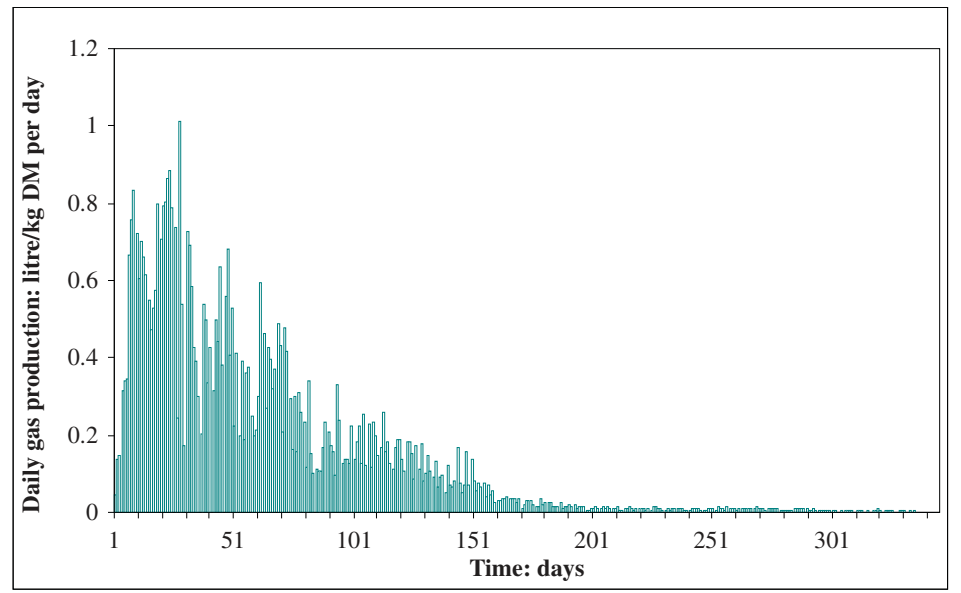

(a)

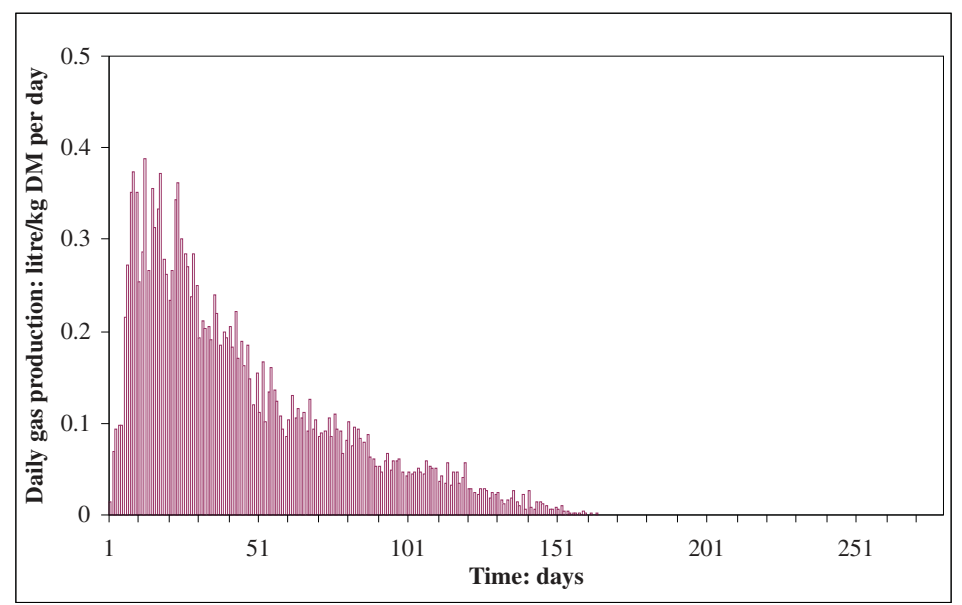

(b)

Figure 2: Daily biogas production in CAR2: (a) UK MBT waste and (b) German MBT waste.

compounds during pretreatment. This is in agreement with the findings of Bayard et al. [9] and Bockeris et al. [24]. Biogas production continued at a much lower rate until day 280 and 195 when it had effectively ceased for the two wastes, respectively. The gassing potential of the German MBT waste was low compared with the UK MBT waste. The total biogas yield was $49.46 \mathrm{~L} / \mathrm{kg}$ DM (litres per kilogram dry matter) and $17.74 \mathrm{~L} / \mathrm{kgDM}$ for the UK and German MBT wastes, respectively. The control reactor, CAR1, for the UK and German MBT wastes did not produce biogas due to the acidification of the reactor with acetic and propionic acids at the start of the experiment.

\subsection{Leachate quality}

The TOC in the leachate was analysed and the results for CAR2 for the UK and German MBT wastes are presented in Fig. 3. The TOC concentration increased during the first week due to the 


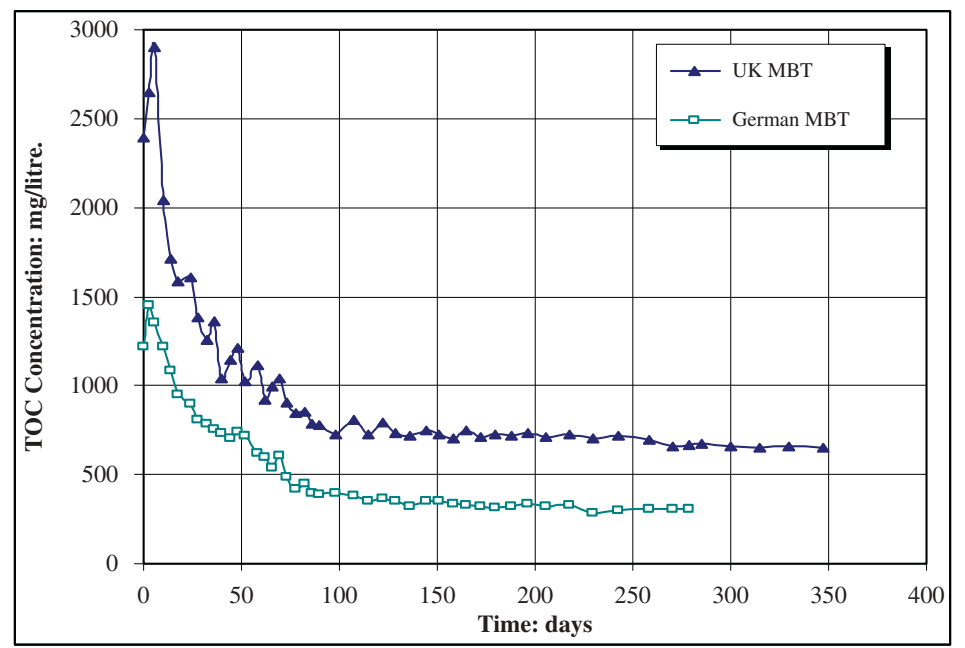

Figure 3: Leachate TOC in CAR2 for the UK and German MBT wastes.

hydrolysis of organics from the waste into the leachate at the initial stage. After the first week, the TOC concentration began to decrease slowly with the progression of stabilisation processes and confirmed by the increase in gas production and the high methane content of the biogas. Towards the end of the study, TOC concentrations were about 650 and $290 \mathrm{mg} / \mathrm{L}$ for the UK and German MBT wastes, respectively. This TOC is mostly recalcitrant or hardly biodegradable carbon present in the reactor as suggested by Kjeldsen et al. [25]. The organic strength, i.e. TOC of the leachate from the German MBT waste, was low compared with that from the UK MBT waste, owing to the different biological processing steps during pretreatment. The German MBT waste was produced after a longer duration (about 9 weeks) of anaerobic and aerobic biological treatment of raw MSW compared with 6 weeks of aerobic biological treatment for the UK MBT waste.

The concentration of ammoniacal nitrogen $\left(\mathrm{NH}_{4}-\mathrm{N}\right)$ in the leachate from CAR2 for the UK and German MBT wastes is shown in Fig. 4. The initial sharp increase in $\mathrm{NH}_{4}-\mathrm{N}$ is the result of direct leaching of ammonia from the waste, and the microbial degradation of nitrogenous organics [26,27]. After an initial increase, ammoniacal nitrogen concentration decreased very slowly to a stable concentration of about 425 and $195 \mathrm{mg} / \mathrm{L}$ for the UK and German MBT wastes, respectively. The results indicated that the nitrogen content in the leachate from the German MBT waste was less than that from the UK MBT waste.

\subsection{Waste settlement}

The CARs were operated at $50 \mathrm{kPa}$ load until day 286 for the UK MBT waste, and until day 202 for the German MBT waste. The load was then increased to $150 \mathrm{kPa}$ for the remainder of the tests to investigate any dependence of the creep characteristics of the waste on the applied load. The majority of the settlement occurred immediately in response to the application of the load which may be due to the lack of compaction of the waste during emplacement of waste in CARs. The primary settlement by the end of $24 \mathrm{~h}$ resulted in additional settlements in the range of 5.9-7.8\% after immediate settlement for the UK and German MBT wastes. 


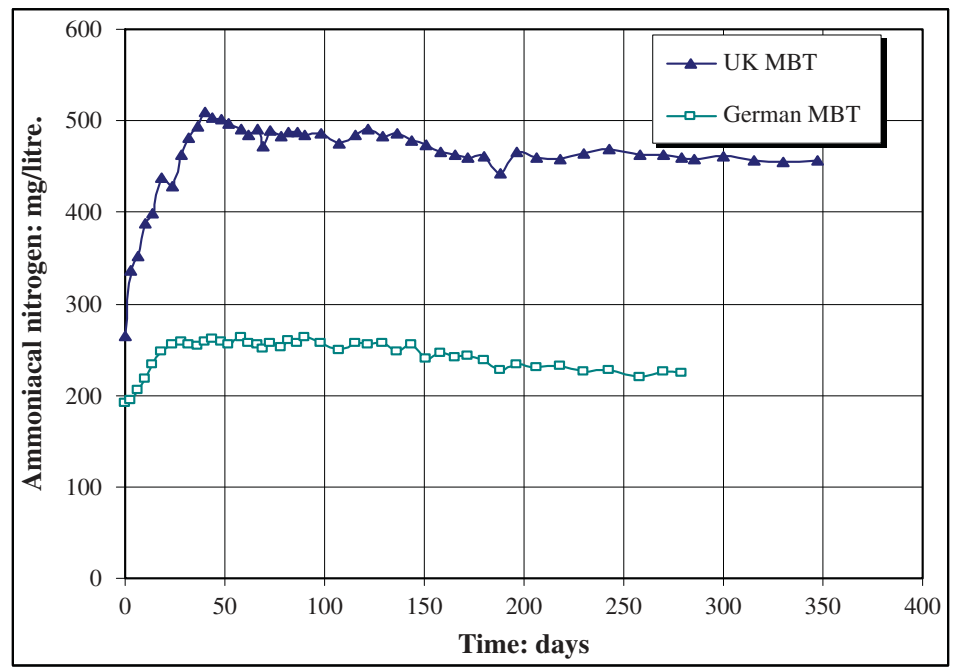

Figure 4: Leachate ammoniacal nitrogen in CAR2.

With data collected from both test and control reactors, it was possible to compare and quantify the net effects of creep and biodegradation on settlement. The total secondary settlement was $5.09 \%$ in CAR 1 and $8.26 \%$ in CAR2 for the UK MBT waste, and $4.09 \%$ in CAR 1 and $5.75 \%$ in CAR2 for the German MBT waste. The rate and magnitude of secondary settlement in CAR2 were higher than CAR1 for both the UK and German MBT wastes due to the decomposition of organics, evidenced by the increase in biogas production and decrease in TOC.

For both wastes, CAR1 remained biologically inhibited over the entire duration of the tests and as a result, settlement may be considered to be due to mechanical creep only. The settlement of the UK and German MBT wastes in CAR2 can be attributed to both mechanical creep and biodegradation. Settlements due to mechanical creep can be isolated from those due to biodegradation, by comparing the settlements measured in each assuming that creep effects were the same in both CARs. Secondary settlement associated with mechanical creep was $5.09 \%$ and $4.09 \%$ and that associated with biodegradation was $3.17 \%$ and $1.66 \%$ for the UK and German MBT wastes, respectively.

\subsection{Hydraulic properties}

The saturated hydraulic conductivity and drainable porosity of MBT waste were investigated at different applied stresses and densities.

\subsubsection{Saturated hydraulic conductivity}

The saturated hydraulic conductivity $(\mathrm{k})$ of the UK and German MBT wastes was determined prior to compression (i.e. at zero applied load) and after compression at applied stresses of 50 and 150 $\mathrm{kPa}$. Over the stress range investigated, the saturated hydraulic conductivity reduced by 2 orders of magnitude, from approximately $7 \times 10^{5} \mathrm{~m} / \mathrm{s}$ at zero load $\left(\rho_{\mathrm{d}} \sim 0.44 \mathrm{t} / \mathrm{m}^{3}\right)$ to about $5 \times 10^{7} \mathrm{~m} / \mathrm{s}$ at an applied stress of $150 \mathrm{kPa}\left(\rho_{\mathrm{d}} \sim 0.71 \mathrm{t} / \mathrm{m}^{3}\right)$. These values are comparable with those reported by Powrie and Beaven [12], Reddy et al. [13] and Bauer et al. [28]. 
For the pre-treated wastes and raw MSW, the variation in saturated hydraulic conductivity with dry density is presented in Fig. 5. The results demonstrate that the saturated hydraulic conductivity is controlled by the vertical stress through its impact on waste density and drainable porosity. The possible reasons for the decrease in $\mathrm{k}$ might be the reduction in pore size and change in geometry and continuity of pores resulting in reduction of fluid flow through the waste.

The decrease in saturated hydraulic conductivity with increasing dry density (Fig. 5) for the pretreated wastes follows the same trend line as for raw MSW and the results are similar for the given range of dry density. The results of pre-treated wastes are consistent with the findings of Powrie and Beaven [12]. The results are also comparable to the range of $7.4 \times 10^{5}$ to $4.6 \times 10^{6} \mathrm{~m} / \mathrm{s}$ reported by Staub et al. [18] for shredded MSW in a small range of dry density from 370 to $530 \mathrm{~kg} / \mathrm{m}^{3}$. Due to

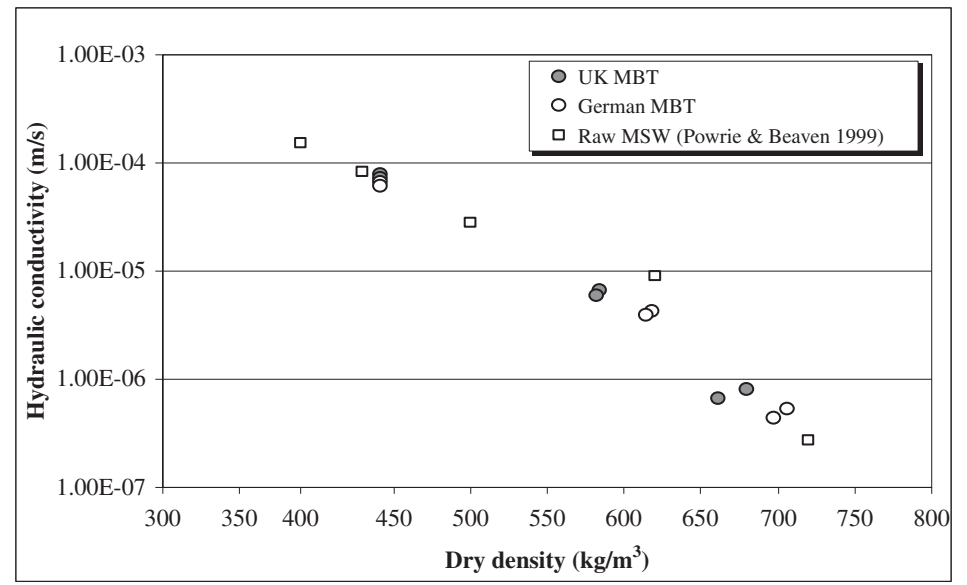

Figure 5: Variation of k with dry density for the pre-treated wastes and raw MSW.

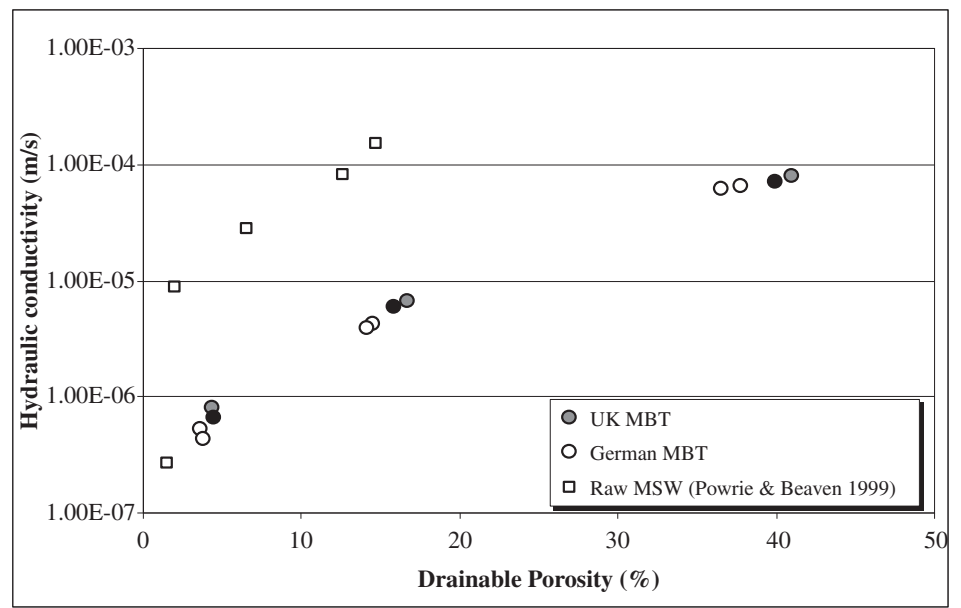

Figure 6: Variation of $\mathrm{k}$ with the drainable porosity for the pre-treated wastes and raw MSW. 
an increase in dry density resulting from the increase in applied stress, the drainable porosity decreases, which causes the saturated hydraulic conductivity to decrease (Fig. 6).

The German MBT waste had slightly lower k values than the UK MBT waste at a given applied stress. The reason could be the obstruction to fluid flow due to the presence of large plastic sheet fragments owing to the larger particle size of the German MBT waste.

\subsubsection{Drainable porosity}

As with the hydraulic conductivity tests, the drainable porosity of the UK and German MBT wastes was determined prior to compression (at zero applied stress) and after compression at applied stresses of 50 and $150 \mathrm{kPa}$.

The results indicate a reduction in drainable porosity at higher applied stress. Initially, both wastes had a relatively large drainable porosity of about $37-40 \%$ before compression, i.e. at zero applied load. This was reduced to about $15-17 \%$ at an applied stress of $50 \mathrm{kPa}$, and to $<5 \%$ at $150 \mathrm{kPa}$. The compaction of waste at higher stress tends to reduce the pore volume and the cross-sectional area of flow paths causing a large decrease in drainable porosity.

Figure 7 highlights a clear trend of decreasing total and drainable porosities with increasing dry density for both the pre-treated wastes and the raw MSW. The total porosities of raw MSW and pretreated wastes are relatively similar with the pretreated waste samples being slightly more porous at lower density. There is little influence of an increase in dry density (resulting from increase in compression) on the total porosity. A change in waste composition and particle size of the pre-treated wastes had a relatively small influence on the total porosity.

For the pre-treated wastes, the loss in drainable porosity on compression is greater than the loss in total porosity. The compression of pre-treated wastes, therefore, has a greater influence, as seen from the loss of drainable porosity which is due to the reduction in drainable voids of the waste owing to changes in waste structure. As dry density increases, the drainable porosity decreases which causes the vertical saturated hydraulic conductivity to decrease (Fig. 6). This behaviour is significantly influenced by the pore structure. Compaction tends to reduce the number and the cross-sectional area of the flow paths, causing a large decrease in the drainable porosity.

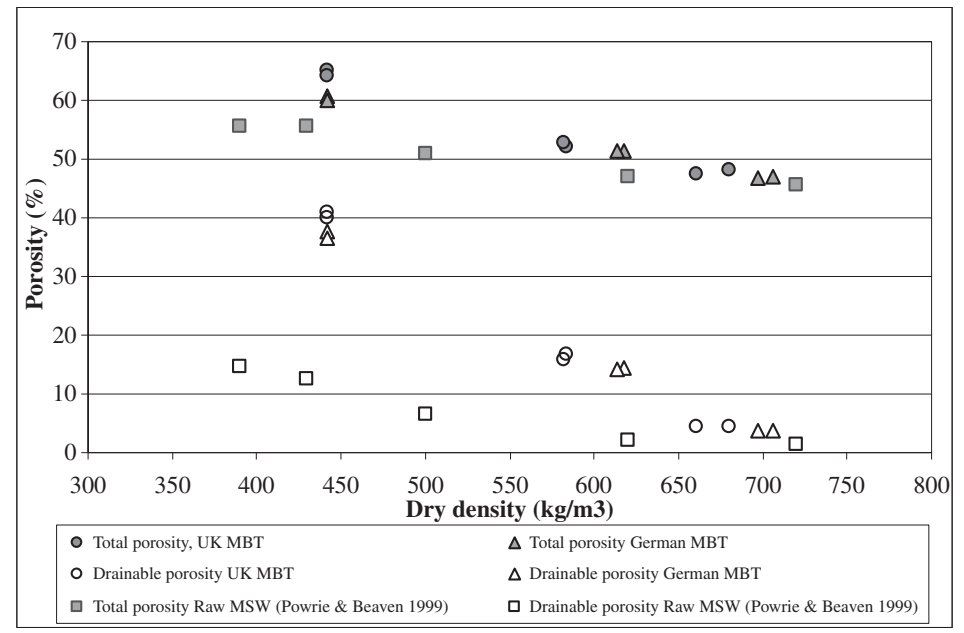

Figure 7: Total and drainable porosities of the pre-treated wastes and raw MSW. 
In comparison to raw MSW, the drainable porosity of the pre-treated wastes seems to display greater values at equivalent dry densities, and the values are comparable at higher density. Nonetheless, the loss of porosity on compression of raw MSW is entirely due to a loss of drainable porosity, i.e. there is a substantial reduction in the pore space available for liquid flow.

\section{CONCLUSIONS}

The gas generation potential, leachate quality and settlements have demonstrated that waste stabilisation was achieved in less than a year under enhanced biodegradation conditions in the CARs for the UK and German MBT wastes. The total volume of biogas produced at STP for the UK and German MBT wastes was 49.46 and $17.74 \mathrm{~L} / \mathrm{kg} \mathrm{DM}$, respectively. The higher gassing potential of the UK MBT waste could be explained by the lower degree of biological pretreatment, evidenced by the higher values of organic content compared with the German MBT waste. Thus, the need to mitigate gaseous emissions will continue with MBT wastes, but the lower rates of gas production must be considered in the size and design of gas collection systems, and also in the economic evaluation of gas to energy projects. The lower rates of gas production may be problematic for effective gas collection and management systems, especially for energy recovery systems.

A significant benefit of waste pretreatment is evident from the reduced level of TOC and ammoniacal nitrogen contents in the leachate, giving a reduced potential for pollution. The organic strength of the leachate from the German MBT waste was low compared with that from the UK MBT waste consistent with the lesser organic content of the German MBT waste. The leaching potential of ammoniacal nitrogen from the German MBT waste was less than that from the UK MBT waste, which was probably due to the lower nitrogen content of the German MBT waste.

Secondary settlement due to mechanical creep was more significant than that due to biodegradation, highlighting the importance of mechanical creep on the overall magnitude of secondary settlement.

Data from both MBT wastes followed the same general trend of decreasing hydraulic conductivity and drainable porosity with increasing stress and waste density. Not surprisingly, the density had a major influence on the drainable porosity values. The saturated hydraulic conductivity of MBT waste samples was in the range $4 \times 10^{6}$ to $6 \times 10^{6} \mathrm{~m} / \mathrm{s}$ at $50 \mathrm{kPa}$, reducing to $5 \times 10^{7}$ to $8 \times 10^{7}$ at $150 \mathrm{kPa}$. The relationships for hydraulic conductivity against dry density are similar for the raw MSW and pre-treated wastes.

\section{REFERENCES}

[1] European Commission Directive 1999/31/EC on the Landfill of waste. Council of the European Union. Official Journal of the European Communities, L182, pp.1-19, 1999.

[2] Rada, E.C. \& Andreottola, G., RDF/SRF: Which perspective for its future in the EU. Editorial. Waste Management, 32, pp. 1059-1060, 2012. doi: http://dx.doi.org/10.1016/j.wasman.2012.02.017

[3] Ragazzi, M. \& Rada, E.C., RDF/SRF evolution and MSW Biodrying, Waste management and the environment. VI. WIT Transactions on Ecology and Environment, 163, ISSN 1743-3541 (on-line), 2012.

[4] Rada, E.C., Franzinelli, A., Taiss, M., Ragazzi, M., Panaitescu, V. \& Apostol, T., Lower heating value dynamics during municipal solid waste bio drying. Environmental Technology, 28(4), pp. 463-470, 2007. doi: http://dx.doi.org/10.1080/09593332808618807

[5] German, E.P.A., Ordinance on Environmentally Compatible Storage of Waste from Human Settlements and on Biological Waste Treatment Facilities (AbfAblV). Federal Ministry for the Environment, Nature Conservation and Nuclear Safety, Berlin, Germany, Available at http:www.bmu.de/english/waste_management/downloads/doc/3371.php,2001. 
[6] Leikam, K. \& Stegmann, R., Influence of mechanical-biological treatment of municipal solid waste on landfill behaviour. Waste Management and Research, 17, pp. 424-429, 1999.

[7] Binner, E. \& Zach, A., Biological reactivity of residual wastes and dependence on the duration of waste pretreatment. Waste Management and Research, 17, pp. 543-554, 1999.

[8] Rada, E.C., Ragazzi, M. \& Venturi, M., Critical analysis of two respirometric method for solid substrates based on continuous and semi-continuous aeration. Journal of Bioremediation \& Biodegradation, 3(12), pp. 1-6, 2012.

[9] Bayard R., de AraujoMorais, J., Rouez, Fifi M.U., Achour, F. \& Ducom, G., Effect of biological pretreatment of coarse MSW on landfill behaviour: laboratory study. Water Science and Technology, 58(7), pp. 1361-1369, 2008. doi: http://dx.doi.org/10.2166/wst.2008.512

[10] Bockreis, A. \& Steinberg, I., Influence of mechanical-biological waste pre-treatment methods on the gas formation in landfills. Waste Management, 25, pp. 337-343, 2005. doi: http://dx.doi. org/10.1016/j.wasman.2005.02.004

[11] Horing, K., Kruempelbeck, I. \& Ehrig, H.J., Long term emissions behaviour of mechanicalbiological pretreated municipal solid waste. In Proceedings Sardinia 1999, 7th International Waste Management and Landfill Symposium, eds. T.H. Christensen, R. Cossu, \& R. Stegmann, S. Margherita di Pula, Cagliari, Italy, 1999.

[12] Powrie, W. \& Beaven, R.P., Hydraulic properties of household waste and implications for landfills. Proceedings of the Institution of Civil Engineers, Geotechnical Engineering, pp. 235-247, 1999.

[13] Reddy, K.R., Hettiarachchi, H., Parakalla, N., Gangatjhulasi, J., Bogner, G. \& Lagier, T., Hydraulic conductivity of MSW in landfills. Journal of Envirironmental Engineering, ASCE, 135(8), pp. 677-683, 2009. doi: http://dx.doi.org/10.1061/(ASCE)EE.1943-7870.0000031

[14] Olivier, F. \& Gourc, J.P., Hydro-mechanics of MSW subject to leachate recirculation in largescale compression reactor cell. Waste Management, 27, pp. 44-58, 2007. doi: http://dx.doi. org/10.1016/j.wasman.2006.01.025

[15] Durmusoglu, E., Sanchez, I.M. \& Corapcioglu, M.Y., Permeability and compression characteristics of municipal solid waste samples. Environmental Geology, 50, pp. 773-786, 2006. doi: http://dx.doi.org/10.1007/s00254-006-0249-6

[16] Stoltz, G., Gourc, J.P. \& Oxarango, L., Liquid and gas permeabilities of unsaturated municipal solid waste under compression. Journal of Contaminant Hydrology, 118(1-2), pp. 27-42, 2010. doi: http://dx.doi.org/10.1016/j.jconhyd.2010.07.008

[17] Hudson, A.P., White, J.K., Beaven, R.P. \& Powrie., W., Modelling the compression behaviour of landfilled domestic waste. Waste Management, 24, pp. 259-269, 2004. doi: http://dx.doi. org/10.1016/j.wasman.2003.12.003

[18] Staub, M., Galietti, B., Oxarango, L., Khire, M.V. \& Gourc, J.P., Porosity and hydraulic conductivity of MSW using laboratory scale tests. 3rd International Workshop Hydro-PhysicoMechanics of Landfills, Braunshweig, Germany, 10-13 March 2009.

[19] Stoltz, G. \& Gourc, J.P., Influence of compressibility of domestic waste on fluid permeability. Proceedings Sardinia 2007, 11th International Waste Management and Landfill Symposium, S. Margherita di Pula, Cagliari, Italy, 1-5 October 2007.

[20] Siddiqui A.A., Richards D.J. \& Powrie W., A preliminary analysis of mechanically biologically treated waste: biodegradation and settlement behaviour. Proceedings of the $12^{\text {th }}$ International Waste Management and Landfill Symposium, S. Margherita di Pula, Cagliari, Italy, 2009.

[21] Florencio, L., Field, J.A. \& Lettinga, G., Substrate competition between methanogens and acetogens during the degradation of methanol in UASB reactors. Water Research, 29(3), pp. 915-922, 1995. doi: http://dx.doi.org/10.1016/0043-1354(94)00199-H 
[22] Beaven, R.P., The Hydrogeological and Geotechnical Properties of Household Waste in Relation to Sustainable Landfilling. PhD Dissertation, Queen Mary and Westfield College, University of London, 2000.

[23] Beaven, R.P., Dollar, L., Oni, O.A. \& Woodman, N.D., A laboratory scale saturated and unsaturated tracer test through waste, International Workshop Hydro-Physico-Mechanics of Landfills, LIRIGM, Grenoble University, France, 21-22 March 2005.

[24] Bockreis, A., Steinberg, I., Rohde, C. \& Jager, J., Gaseous emissions of mechanicallybiologically pre-treated waste for long term experiments. Proceedings of the 9th International Waste Management and Landfill Symposium, S. Margherita di Pula, Cagliary, Italy, 2003.

[25] Kjeldsen, P., Barlaz, M.A., Rooker, R., Baun, A., Ledin, A. \& Christensen, T.H., Present and long-term composition of MSW landfill leachate: a review. Critical Reviews in Environmental Science and Technology, 32(4), pp. 297-336, 2002. doi: http://dx.doi.org/ $\underline{10.1080 / 10643380290813462}$

[26] Berge, N.D., Reinhart, D.R. \& Townsend, T.G., The fate of nitrogen in bioreactor landfills. Critical Reviews in Environmental Science and Technology, 35(4), pp. 365-399, 2005. doi: http:// dx.doi.org/10.1080/10643380590945003

[27] Jokela, J.P.Y. \& Rintala, J.A., Anaerobic solubilisation of nitrogen from municipal solid waste. Reviews in Environmental Science and Biotechnology, 2, pp. 67-77, 2003. doi: http://dx.doi. org/10.1023/B:RESB.0000022830.62176.36

[28] Bauer, J., Munnich, K. \& Fricke, K., Investigation of mechanical properties of MBT waste. Proceedings of the 4th Asian-Pacific Landfill Symposium, Shanghai, China, 2006. 